\title{
The contribution of school culture to the learner success factors in e-learning
}

\author{
R. Chusnu Yuli Setyo \\ chusnusetyo@mhs.unesa.ac.id \\ Universitas Islam Lamongan, \\ Jl. Veteran No 56A Lamongan, Indonesia \\ Suharsono Suharsono \\ suharsono@unesa.ac.id \\ Universitas Negeri Surabaya \\ Jl. Ketintang Surabaya, Indonesia \\ Oikurema Purwati \\ Pungki_unesa@yahoo.co.id \\ Universitas Negeri Surabaya \\ Jl. Ketintang Surabaya, Indonesia
}

Received: June 29,2018; Accepted: September 14, 2018; Published: September 20, 2018

\begin{abstract}
This study aimed to portray how a school culture contributed to the learner success factors in e-learning in the middle school level. The ethnographic case study design was applied to explore the school culture and the e-learning success factors more deeply and holistically. The data were collected through observations and in-depth interviews. The cross-case analysis was used to interpret the data. The subjects of the study were four students who won in the national e-learning competition and the setting of the institution was in SMP Tentara Genie Pelajar (TGP) in Malang. The fundamental finding of the study, that might not be found in other research, was that the high-academic performance culture of this school gave an indirect contribution to the students' e-learning success factors, such as the students' motivation, the students' elearning self-efficacy, the students' prior knowledge on the e-learning technical competency, and the students' interaction and collaboration. This study gave a big implication because an ethnographic case study on the e-learning critical success factors might be never done in Indonesia before.
\end{abstract}


Keywords: e-learning critical success factors, ethnographic case study, school culture

How to cite this paper: Setyo, R. C. Y., Suharsono, S., \& Purwati, O. (2018). The contribution of school culture to the learner success factors in e-learning. Journal on English as a Foreign Language, 8(2), 149-169. doi:http://dx.doi.org/10.23971/jefl.v8i2.884

DOI: http://dx.doi.org/10.23971/ßefl.v8i2.884

The success of SMP Tentara Genie Pelajar (TGP) in Malang Regency to implement an e-learning platform for a teaching and learning process was interesting to be explored. SMP TGP was a public middle school which was located in one village but ten of its students successfully won in the national elearning competition held by Quipper School Company in 2014. Moreover, this school got a second place as the best class in the inter-class competition in the same event. It meant not only its students were successful, but also the institution. It was an interesting phenomenon because this school could beat other schools in big cities that had better e-learning facilities. The success of the students attracted me to visit this school to do a preliminary research. Interestingly, four of ten students who still sat in the seventh and eighth grade got a significant improvement on their English competencies. After they had learned English through the e-learning Quipper School for almost six months, their English competencies increased. Of course, it was a rare and unique case.

The achievement of SMP TGP in the national event was a proof that the school with its limited e-learning facilities and with its varied economical background of the parents could implement e-learning successfully. It was good news because, in general, the implementation of e-learning in Indonesia was facing numerous challenges and limitations, especially related to access and quality of internet, its regulation, budget, infrastructure, and human resources (Ali, 2005), no standard in the contents (Sulistyo, 2007), low quality of teacher (Son, et al., 2011) and low independence level of students to learn (Kusumo, Kurniawan, \& Putri, 2012). Moreover, e-learning development in Indonesia had not earned satisfactory results around for 15 years because the networked readiness index still did not support the e-learning readiness.

According to World Economic Forum (2016), the networked readiness of Indonesia was still in the 73rd rank, out of 139 countries. These challenges and limitations caused many schools in Indonesia did not apply e-learning as a big jump to prepare the digital native students to face an Industry Revolution 4.0. 
This revolution is coming around the world. Moreover, the use of the computer and internet for learning had significant effects on language in general, on second language classroom (Dudeney \& Hockly, 2007), and on English language teaching (Noytim, 2006). It was in line with Eagleton and Dobler (2007) who found that the computer and internet literacies were essential for the middle school students.

Unfortunately, most English teachers in developing countries have the crucial problems of a low literacy in using the computer and the internet (Son, Robb, \& Charismiadji, 2011). In short, the digital-native students are in the digital era now and they also will work by using digital technologies. Hence, a radical change in the education policy should be taken to implement massively e-learning in Indonesia schools. Based on the rationale above, a case study of the e-learning success of SMP TGP is very significant especially for the students, teachers, headmasters, and educational policymakers to succeed the implementation of e-learning in their institutions and generally in Indonesia.

According to Selim (2007) and Zainon, Masrom, and Rahiman (2008), elearning success was mainly influenced by the instructor factors and student factors, such as motivation to use e-learning and student computer competency. In his dissertation, Ordóñez (2014) summarized e-learning critical success factors (CSFs) into three; learner factors, institutional factors and outcome factors. Learner factors were the success which was influenced by the students' factors, such as motivation, self-efficacy, prior knowledge, and course expectation. Next, institutional factors were the success which was influenced by the institutional factors, such as learning support, social presence, direct instruction, learning platform, instructor instruction, learning content, and course design. Then, outcome factors were the success caused by the process factors (institutional factors), such as student satisfaction, knowledge acquisition and knowledge transfer. Before that, Ordóñez and Barbera (2013) stated that cultural issues, especially the students' cultural background, influenced learner and institutional factors. However, strangely, Ordóñez (2014) did not put a culture as a determinant factor of the e-learning success in his dissertation.

According to Brown (2002), e-learning was the result of an extraordinary social process that happened not only in the school environment but also in the community where students lived. That was why e-learning was a result of a social framework that fosters learning. Not only the social process in learning but also the learning theories were also the reflection of the underlying social environment. It meant schools were social institutions and affected by their surroundings and the schools' individuals were surrounded by school culture (Ali, Sharma, \& Zaman, 2016). Hence, exploring the contribution of school 
culture to the e-learning success could help to understand the social process of the students in the classroom or out of the classroom.

The missing of culture factor in Ordóñez's (2014) study inspired the researcher to explore the contribution of school culture factor to the e-learning success because it was assumed that the success was influenced by the culture of this school. The school culture influenced the students' beliefs, motivations, and achievements. Boeije (2010) said that "qualitative research generally starts with the assumptions that individuals have an active role in the construction of social reality." Ali et al. (2016) also supported this assumption because they found that there was a significant relationship between school culture and school effectiveness. In fact, not many studies on e-learning CSFs explored the culture of the school as an institution. Most of them discussed the culture of students. For example, Kinasevych (2010) conducted survey research cultural values of students that effected on the online learning. Almost the same with the last researcher, Aparicio, Bação, and Oliveira (2016) put the students' characteristic culture as the determinant factor of e-learning success. Hence, this study aimed to portray how school culture of SMP TGP contributed to the learners' success factors in e-learning.

The function of Critical Success Factors (CSFs) is to define the things or factors that "must go right" for an organization to achieve their purposes, missions, or objectives (Howell, 2010). Thus, e-learning CSFs are viewed as the critical things or factors that must be done for students, teachers or institutions to make learning through e-learning successful (Zainon et al., 2008). In this study, e-learning is defined as instructions delivered via electronic media and supported with digital learning contents and services in the computer, communication and internet technologies to create, deliver and facilitate learning, anytime and anywhere (Mason \& Rennie, 2006).

It was interesting to know that most e-learning CSFs were identified by using quantitative approaches, such as Selim (2007), Sun, Tsai, Finger, Chen, and Yeh (2008), De Sousa (2011), Musa and Othman (2012), and Ordóñez (2014). Different from those researchers, Sridharan (2011) in his dissertation used an ethnographic case study design to compare qualitative and quantitative findings based on the e-learners' perception. He found that adopting pedagogical strategies (adaptive, collaborative, explorative, interactive, concept map, and blended) positively influenced the e-learning effectiveness. This dimension was viewed to be critical in qualitative findings but it was not critical in quantitative ones. The use of the ethnographic case study design triggered me to apply it in this study because it was rarely applied, especially by Indonesian researchers. 


\section{METHOD}

This study applied a qualitative method because of the following reasons. The direct source of data was from a natural setting in SMP TGP. As the researcher of this study, I was the key instrument in data collection and data analysis. The data collected was in the form of words, texts, videos, photographs, and sound recordings (Yin, 2011; Fraenkel, Wallen, \& Hyun, 2012). The design of the research was an ethnographic case study. An ethnographic research design was applied to portray a holistic culture of the groups in SMP TGP by observing and interviewing the everyday experiences of individuals (students, teachers, and headmaster) (Fraenkel et al., 2012).

Meanwhile, a case study research design provided an empirical and indepth investigation of a particular contemporary case (an e-learning success) within a real-life world context (a school culture of SMP TGP) (Creswell, 2007; Yin, 2011). School culture could not happen instantly but as something that was continuously generated and maintained by societal members of school through a continual process of interpretation. To be able to interpret what was happening in the ongoing social interactions at school, the ethnographic design was applied. Moreover, this study needed more than a one-year period of fieldwork and it was considered as a longitudinal research because the research was done on over several time-period. It started from 21 February 2015 and it finished on 31 March 2017.

The field setting was focused on two settings; they were the subject setting and the institutional setting (Anderson-Levitt, 2006). The subject of the study was four students of SMP TGP who successfully won the national elearning competition and who got an improvement of their English competencies after learning by using Quipper School. Subject R and Subject W were in the ninth grade. Subject $A$ and Subject $M$ were in the eighth grade. Meanwhile, the setting of the institution was in SMP TGP. This middle school was located in a village in Malang, East Java. All subjects studied in the bilingual class. One of the programs of the bilingual class was the additional learning materials and exercises through an e-learning Quipper School. This Quipper School was introduced by Instructor T to this school in August 2014. Quipper School was a free e-learning platform that consisted of a content course (teaching materials and assessments) and could be accessed through PCs, laptops, or handphones.

The data collection method was by using observation, in-depth interview, and documentation. The in-depth interviews were collected from four subjects of the study. Then, the data taken from interviews was triangulated to other different sources, such as; the observations in the computer laboratories, in the classrooms, in the Wi-Fi hotspots, and other places

Journal on English as a Foreign Language, 8(2), 149-169

Copyright (C) 2018 by JEFL, p-ISSN 2088-1657; e-ISSN 2502-6615 
at this school; the interviews with other students, the IT instructors, the English teachers, and the vice principal for curriculum affairs; and the documentation related to the students' academic book reports, achievement certificates, and schools' achievements.

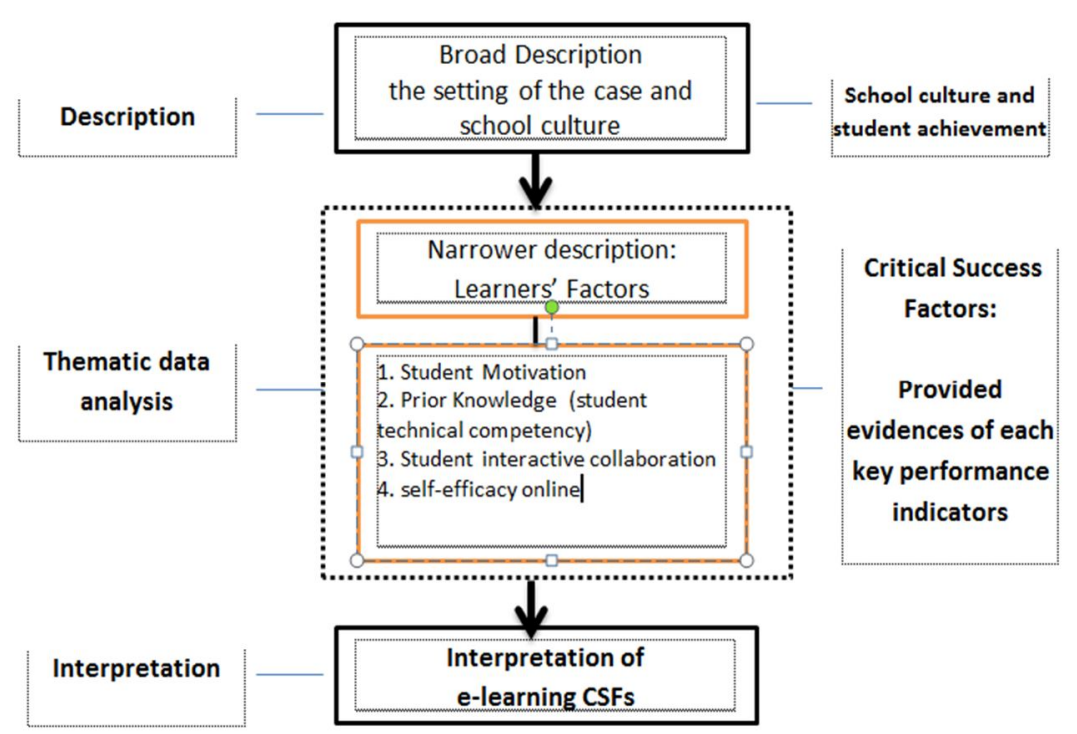

Figure 1. The Broad-to-Narrow Description of Data Analysis in an Ethnographic Data Analysis (Adapted from Creswell, 2008)

The data analysis procedure in this ethnographic case study consisted of five steps: (1) data managing, (2) coding and developing themes, (3) describing, (4) interpreting, and (5) representing (Creswell, 2008). Organizing the data or data management begins the process of data analysis. The researcher organizes data into file folders and computer files. After that, the researcher reads the data and makes notes using short phrases, ideas, chart, or key concepts related to the research questions. These phrases, ideas, and key concepts are identified in codes or categories that could be applied to words, phrases, or sentences within the data. The coded data were categorized based on the kinds of CSFs, especially the learner factors. They are (1) student's motivation, (2) students' prior knowledge on computer and internet literacy, (3) students' interactions and collaborations, and (4) Students' e-learning self-efficacy. The process of establishing codes and themes has implications for descriptive reporting and theory building. Coding is a crucial aspect of analysis (Basit, 2003). Describing the data based on the categories of CSFs is the next step. In this step, a crosscase analysis was applied to analyze the coded data because every subject had their own experiences or cases to be successful digital native students.

According to Klenke (2008), a cross-case analysis could be used to compare the commonalities and differences in the events, activities, and Journal on English as a Foreign Language, 8(2), 149-169

Copyright (C) 2018 by JEFL, p-ISSN 2088-1657; e-ISSN 2502-6615 
processes that existed in the units of analyses in case studies. The interpretations across individual cases of the subjects showed the similarities or dissimilarities to be successful students. According to Creswell (2008), a description of ethnography is to describe from general picture to the specific setting in which an event or events take place. He suggests a broad-to-narrow description in analyzing e-learning CFSs of the e-learning learners (see Figure 1). Moreover, by interpreting the same categories or themes from the similarities, the conclusion could be drawn. Moreover, to strengthen the validity of this research, five strategies were applied including intensive longterm (field) involvement (from 21 February 2015 up to 31 March 2017), rich data, respondent validation, rival explanation, triangulation, and comparison of explanation.

\section{FINDINGS}

\section{A High-Academic Performance Culture}

SMP TGP was built by the alumni of Tentara Genie Pelajar (TGP) on January 23, 1979. Some alumni who had been retired from military or veterans chose Marsekal Madya Aried Riyadi to be the leader to build a school building for a middle school. They built a school building because the people near the school building helped them to supply food logistics during the Dutch colonialism. Since this school was built by the war veterans and military retirements, the characters of the students and teachers, regulations, curriculum, and traditions of the school were influenced by their heroism spirit and discipline. It was stated by a second-year alumnus of SMP TGP who became an elementary school teacher in Blitar, the next district of Malang, this school had a tradition that was inherited since SMP TGP was built. She said:

"Masih dari dulu itu setiap 10 Nopember. Itu kita peringati sebagai Hari Pahlawan dan siswa-siswinya pakai pakaian pejuang semua. Serta bapak ibu gurunya. Pendidikan ekstranya itu benar-benar ditekankan. Sampai sekarang pun di sana itu yang ditekankan adalah ekstra. Anak-anak banyak yang berhasil menjuarai apa kejuaraan di tingkat nasional, kabupaten, maupun kecamatan. Dan di sana juga ditiru oleh SMP-SMP lain di kecamatan $S^{* * * * * * * * * \prime .}$

According to the alumnus above, wearing heroic clothes for all students and teachers in every Hero's Day of 10 November was one of the traditions in SMP TGP since it was built. The other good tradition was the emphasis of the extracurricular lessons. She believed that the students could get achievements in the sub-district up to the national level because the extracurricular lessons were really emphasized to the students. The success strategy of this school to get many achievements was imitated by other schools near it. The school principal justified her statements by saying:

Journal on English as a Foreign Language, 8(2), 149-169

Copyright (C) 2018 by JEFL, p-ISSN 2088-1657; e-ISSN 2502-6615 
"The nationalism and discipline of this school were influenced by the name of Tentara Genie Pelajar. The nationalism was built in every moment, such as on 10 November. The students were wearing heroic clothes".

The success strategy above was also supported by the vice principal who said that this school had 31 extracurricular activities, such as Scouts, Marching Band, Quipper School, Story Telling, English Speech, Indonesian Speech, Poetry Reading, Indonesian Red Cross, Volley, Batik, Folk Song, Traditional Dance, Silat, Karate, Calligraphy, Qiroat, Kasti, Science Olympiad, Photography, football, and others. Almost all extracurricular lessons above ever won in the competition events during 2013-2016.

The success of this school to win in many competitions was supported by nine unwritten school systems which had been implemented for many years and become traditions and culture. First, to develop the students' talent and interest, this school opened many kinds of extracurricular lessons. In 2016, there were 31 extracurricular activities. As the result, the outstanding extracurricular and intra-curricular activity of this school became one of the attractions for elementary school students to register and study here.

Second, each extracurricular was given a short time to promote their activity and program to fresh students during the student orientation time in the early month of the academic period. In this promotion, every extracurricular shown their achievements to attract members as many as possible. This activity increased motivation and proudness of the students to study here.

Third, all extracurricular activities were facilitated with facilities needed and with instructors to train the students. The other interesting system is the instructors were chosen from their own teachers that had an ability, experience, and time to train the students. All teachers and staffs were supposed to have the ability to handle the extracurricular activities.

Fourth, all students were obliged to join, at least, two extracurricular activities. There was a two-month trial time for students. If a student was not active twice in a month and it happened up to two months, the instructor suggested the student move or to find another extracurricular activity.

Fifth, to maximize the school achievement, this school had a bilingual class in which its students were always ready to follow many events or competitions. 34 students of this class were selected from 350 students based on their test, IQ, motivation, and parent's support. The academic score was gotten from the test of Indonesian, mathematics, science, social, English, and IT courses.

Sixth, to develop the student confidence and leadership, the students were not only taught with learning materials, but also with leadership training 
in a school organization. As the result, the outcome of the extracurricular lesson could be seen when the student studied in senior high school. Many of them got a top rank in class and they were very confident and they became the leaders in a class, OSIS, or extracurricular activities

Seventh, the good relationship between teachers and students could increase the students' motivation. The close and good relationship was always kept not only while the student were studying at this school but also while they were at home. Even, after they graduated, this relationship still runs well.

Eighth, the teachers had a high awareness and commitment to teach on time. They were much disciplined. This discipline character was imitated by their students. Last, this school provided many events for a school competition and for a place of student performance.

Exploring the traditions, beliefs, system, and relationships in the school could portray holistically the high academic performance culture of the school. It could be seen that this school got 20 achievements in the regency, province and national level in 2013. It increased to be 31 ones in 2014, and 24 in 2015 and 32 achievements in 2016. It seemed that the achievements reached by the school seem to get rising every year. The brief description of the school system opened and related the understanding, significance, and meaning of the school culture to the success of the students this school, especially the success in e-learning. Based on the description of the school culture, the critical success factors from the learners' factors could be explored.

\section{The Contributions of the School Culture to the Learners' E-Learning Critical Success Factors}

According to Ordonez (2014), the e-learning success was influenced by a learner factor and institutional factor. In this study, e-learning success was only seen from the learner factors. The learner factors of the e-learning success consisted of student's motivation, student's prior knowledge, student's interaction and collaboration, and student's e-learning self-efficacy. The success of the students in e-learning was influenced by the indirect contribution of a high academic performance culture of this school to the following e-learning success factors, as described below.

\section{Students' Motivation and School Culture}

Based on the interview with the subjects and supported with the interview with the ninth grade students that I accidentally met in front of the class and the homeroom teacher of the bilingual class where the Subject $\mathrm{R}$ and W studied, it could be seen that the students had a high motivation to study here. When I asked, "What is the most influencing factor that causes you to 
become the winner?" Subject R said, "The student's factor and teacher's factor influence the success". This data was also supported by Instructor B who said that the critical success factors of the subject and the students to be the winner are because of the students' motivation. The subject $R^{\prime}$ s answer was also supported by other students.

When the researchers went to the teacher's office, they met with three students who were in the different class with the subjects of the study. I asked them, "What are your motivation to study Quipper School...Can Quipper school improve your English?" All students answered, "Yes, it can." Besides, when I asked about what factors made the subjects win in the Quipper School competition, one of the students answered that it was caused by the instructor's factor and student's factor. When I confirmed to Subject M and Subject A, both of them agreed with one of the students above who said, "Here (in this school) the students have a high motivation to learn because this school had many achievements." Subject $\mathrm{R}$ said that she was motivated to do the best in elearning because she saw many trophies put in the headmaster's room, vice headmaster's room, language laboratory, computer laboratory, teacher's room, and big glass cabinet beside the headmaster's room. It could be seen that the big cabinet was not enough anymore to display the championship trophies. The trophies were proof that this school had a high-performance culture.

A positive tradition in a Bilingual Class also gave a motivation to the subjects to learn in a high competition. As the students of Bilingual Class, Subject $\mathrm{R}$ and Subject $\mathrm{W}$ often competed with other students to get high scores. Both of them were good in mathematics since in the seventh grade but their English competency was in average. After learning by using QS, there was an improvement in their English competency. Moreover, the competition among students of the Bilingual Class led the subjects to do the quizzes and tests on QS as many as possible.

Hence, the frequency of using QS could show the motivation of the students. It could be seen in the students' statistics of the TGP Virtual Quipper Class that Subject R completed 741 topics and mastered 733 topics. The topics were not only English lessons and exercises, but also mathematics, science (physics and biology), and IT courses. From 741 general topics, she mastered 220 English topics. Meanwhile, Subject W completed 372 topics, mastered 368 topics, and mastered 98 topics of English course. Subject M finished 309 topics, mastered 306 topics, and mastered 96 English topics. The last, Subject A accomplished 294 topics, mastered 290 topics and mastered 66 English topics. Subject $\mathrm{R}$ was the most active student in SMP TGP. She liked to study individually and independently at home. Studying individually meant she preferred doing exercises alone to doing together with her friends. Studying 
independently meant she did exercises as many as possible without being waiting for the teacher's or instructor's commands. Subject $\mathrm{R}$ was a special case that I found in this school. When the e-learning national competition was held in one week and she preferred doing the quizzes individually. Student R said that:

"Lombanya itu seminggu. Seperti saya bilang dulu. Pokoknya semangat saja mengerjakan sebanyak-banyaknya. Benar atau salah kerjakan saja. Di sekolah, pulang sekolah, dan di rumah. Saya banyak mengerjakan sendiri".

According to Subject R, the key of her success in the e-learning competition was by doing the test items as many as possible. She opened all the materials and then she finished the tests as soon as possible without paying attention to her answers whether they were right or wrong. By this strategy, she collected many scores and finally she became the first winner in the national competition.

The description of the school culture and the experiences of the students above showed that the school culture gave an indirect contribution to the elearning success through the improvement of the students' motivation. The high motivation made the students more frequent to learn via the e-learning QS. It seemed that the students who had a high motivation were more active or more frequent to finish the quizzes and tests in the e-learning QS. The subjects of the study believed that the students' motivation was the critical factor to succeed e-learning.

\section{Students' Prior Knowledge on Computer and Internet Literacy}

The implementation of e-learning in SMP TGP could not be parted with the contribution of Instructor T. He had a high motivation to implement elearning in this school. Instructor $\mathrm{T}$ was the first winner in the learning web competition held by East Java Provincial Education Board in December 2015. One year before, in December 2014, ten students became the winners in the national e-learning competition. Being the winners was not from a short process. The students and the instructor needed a long time to prepare it. The lesson about computer skills or programs had been taught to the students since they were in the seventh grade. The internet skills were introduced in the eighth grade.

According to the vice headmaster, the students who studied in the Bilingual Class were very lucky because they were taught by Instructor T. The homeroom teacher of the Bilingual Class 8.1 also acknowledged that the development of the computer literacy of the students was good. He saw that the students often helped him when he got troubles in operating a powerpoint program (slides) with an LCD projector or in editing the word typing. The 
English teacher also saw that the students of this class were very familiar to operate their laptops when he gave a remedial test by using the e-learning QS. Thus, Instructor $T$ had taught them the computer and internet literacy before the e-learning QS was applied. It meant that the computer and internet literacy contributed to the e-learning literacy. The habit and values of the Bilingual Class gave an indirect contribution to the students to use digital learning tools in their class.

Besides, the good relationship between Instructor $\mathrm{T}$ and the students gave a contribution to the students' success because it could increase the students' self-confidence. Moreover, the school tradition to win in many contests or competition also increased their motivation to succeed in e-learning. This tradition brought SMP TGP to be a school with a high academic performance culture. Meanwhile, the e-learning would not be successful if the students did not have a prior knowledge on the e-learning technical competency. The e-learning technical competency was acquired from the computer and internet literacy. Hence, it could be said that a school culture gave an indirect contribution to the e-learning success through the students' prior knowledge.

The brief description of the school culture and the prior knowledge could be read below. In August 2014, Instructor T introduced e-learning Quipper School and he made a Virtual Class TGP, a virtual class of Quipper School. The reason to open this virtual class was to fulfill the demands of many students who wanted to open QS after school and needed to use the computer laboratory. Since August 2014, all students were taught how to learn by using elearning QS. Even though the number of the computers in the computer laboratory was not enough for all students in one class, all students still enthusiastically learned it in different ways. Since not many students had a laptop, they learned together by using a laptop which belonged to one of the students. They learned it near a Wi-Fi hotspot. To do a task given by their teacher, the students went to an internet café. QS could be accessed through computers, laptops, Android tablets, and smartphones wherever they were. After school hours, they usually used the computers in the laboratory and those who had laptops, tabs, or smartphones accessed QS by using free Wi-Fi around the hall building. It was very interesting to know that almost all students of SMP TGP knew how to access and operate e-learning QS. When I interviewed randomly the students that I met at school, almost all students knew about elearning QS. 
The implementation of e-learning above was influenced by the students' prior knowledge on computer and internet literacy. The ability to open and access QS was influenced by their ability to use the computer and to access internet services. Based on the results of the structured interview to the winners of the national e-learning competition, especially about their prior knowledge on the e-learning technical competency (the computer and internet competency), it could be seen that their competency was better than the other students. Subject $\mathrm{R}$ and Subject $\mathrm{W}$ had a good computer and internet competency. Both of them could operate a computer since in the fourth grade of the elementary school and they could internet since the first grade of the middle school. Their computer and internet literacy developed fast when they learned in this school. Then, these competencies helped them to operate the e-learning QS. Their skills were intermediate in word processing application and spreadsheet application. It was supported by the frequency of using word processing 3-4 times a week. For spreadsheet, Subject W used it 3-4 times per week but Subject $R$ used 1-2 times per week. For browsing a web on the internet, both of them do it 1-2 times per week because they had a computer (laptop) connected to the internet at home and at school. Meanwhile, they were in online discussion group and text chatting in social media like a Facebook almost every day. Subject $\mathrm{R}$ had an account on Facebook, Instagram, and Tweeter. Meanwhile, Subject $\mathrm{W}$ had a Facebook and Instagram but her Instagram is not active. The description above was supported with their selfevaluation about their "good rate of their computer, internet, and e-learning literacy.

Meanwhile, Subject $\mathrm{M}$ was sure that his computer and e-learning literacy were excellent. His internet literacy was good because he mastered web search engines and communication applications in an advanced level; word processing applications, spreadsheet applications, multimedia applications, and web design applications in an intermediate level; and presentation applications in a basic level. He had been using computers for seven years and someone who taught how to use computers was a family. His frequency of using computer applications showed that he enjoyed using a computer and an internet. $\mathrm{He}$ opened e-mail, world wide web, e-learning Quipper School, computer games and text chatting almost every day; opened multimedia (audio and video) 3-4 times per week; used word processing, spreadsheet, wiki, and voice chatting 12 times per week. His good digital literacy was supported by the internet access and computer (PC) at home facilitated by his parents.

Subject A had a little bit difference of his prior knowledge compared with Subject M. He rated his computer, internet and e-learning literacy at a good level. Learning computer for the first time five years ago from his family 
who brought a laptop to his house. Since at that time, he had been interested in a computer. His father bought him a laptop when he was accepted in the bilingual class 7A. His good internet and computer literacy were proved by his skills of using web search engines and communication applications in an advanced level; word processing applications, spreadsheet applications, presentation application, multimedia applications, web search engines, and communication application at an intermediate level. His data applications were in a basic level. His computer and internet literacy was seen from his frequency of using computer and internet applications. He opened world wide web, elearning Quipper School, computer games and text chatting almost everyday; opened word processing, e-mail, multimedia (audio and video) 3-4 times per week; used spreadsheets, and voice chatting 1-2 times per week.

All prior knowledge of the subjects mentioned above was the result of the interview and I could not check or clarify one by one. However, based on the observation of how they opened a laptop, connected to the internet, and then operated the e-learning QS very fast, they had a good competency on the computer and internet literacy. It seemed that the good prior knowledge on the computer and internet literacy caused the students to operate more easily the elearning QS. Since the subjects did not find any difficulties, they felt comfortable to learn by using e-learning. Thus, it could be said that the new culture of e-learning in SMP TGP gave an indirect contribution to the e-learning success

\section{Students' Interactions and collaborations}

The students' success in e-learning was also from the contribution of the students' interaction and collaboration in doing the quizzes or tests. There were three kinds of learning interaction that happened during e-learning class, they are (1) the interaction between student-student, (2) student-instructor, and (3) student-content (e-learning content). How these interactions gave a contribution to the success could be described below.

Based on the observation, it could be seen that the subjects $\mathrm{R}$ and $\mathrm{W}$ often completed the quizzes by themselves. Subject $\mathrm{R}$ and Subject $\mathrm{W}$ said that the interaction between the students and the instructor could influence her ability to overcome any technical problems she faced. The interaction between the instructor-student also happened asynchronously on the QS. The instructor gave a message to the students on the right top corner of the main page but it was not effective. I saw only Subject $\mathrm{W}$ who was active to answer or respond to the message from Instructor $\mathrm{T}$. Instructor $\mathrm{T}$ was the Information and Technology (IT) teacher. The instructor-student interaction often happened on a

Journal on English as a Foreign Language, 8(2), 149-169

Copyright (C) 2018 by JEFL, p-ISSN 2088-1657; e-ISSN 2502-6615 
face to face interaction. This interaction helped the students very much related to the technical problems in operating the e-learning platform.

The next interaction was the student-student interaction. It also happened in the QS class. This interaction tended to make the students to work together or to collaborate. Subject $\mathrm{R}$ and Subject $\mathrm{M}$ said that the students could discuss with others to solve the quizzes in Quipper School. It happened when they learned together in the computer laboratory or in the hotspot area. They did not interact or collaborate with each other when they learned at home. Subject $\mathrm{M}$ and $\mathrm{R}$ believed that the learner-learner interactions when doing quizzes or test exercises in Quipper School helped him to collect points as many as possible. Subject M said, "the student's factor because the students can help each other. If they cannot solve the problem, they can ask to be taught to each other". This kind of interaction was often done by Subject M but it was rarely done by Subject $R$. Subject $R$ and Subject $W$ preferred doing the exercises individually.

The last kind of the learning interactions was the student-content interaction. This interaction fully happened in online learning QS. The students had to sit in front of PC or laptop to learn the materials and to do the quiz. They had to read the instructions and to do the quizzes step by step. The interaction of the students with the e-learning content could be seen from their frequency in opening QS. The students' statistics of the TGP Virtual Quipper Class, as stated above, showed that all subjects of the study were very active to interact with the learning contents on QS.

\section{Students' E-learning Self-Efficacy}

The booming of learning by using e-learning became a new culture in this school. The students brought their laptops to the class every day. They could use their smartphones after school and access two free Wi-Fi hotspots at school. The teachers started to use their laptop to upload tasks or tests and then they checked the result of their students' tests. The school added the internet bandwidth. The students who had no a computer, a laptop, or a smartphone and had no an internet access at home, they went to 'an internet café', one type of entrepreneurship that rented internet services to the public. The English teachers asked their students to enrich their knowledge by reading the learning materials in the related course contents in QS.

Based on the observation to the subjects, all subjects who had a good prior knowledge on the e-learning technical competency also had a high selfefficacy in e-learning. Subject $R$ and Subject $W$ had a strong sense of efficacy on e-learning. They had a high belief in their capabilities to finish tasks or quizzes in learning English with e-learning. Their good literacy on computer and 
internet helped them to accomplish the tasks and quizzes given in the QS. Moreover, the instructor-student interaction also could improve their selfefficacy. As stated before, the good relationship between the instructor and the student could improve their motivation and self-efficacy. Instructor $\mathrm{T}$ and English teachers were very friendly and helpful to the students. That was why the students were successful in e-learning. Hence, it could be said that the school culture gave an indirect contribution to the students' e-learning success.

\section{DISCUSSION}

The success of the students and institution of SMPN TGP in e-learning was not only the contribution of the learner factors and institutional factors but also the indirect contribution of the school culture factor. Interestingly, the indirect contribution of school culture factor towards the e-learning success was rarely explored and described in details. So far, most data of e-learning CSF research was derived from a survey method to know critical success factors, not how and why factors could exist in the field of study.

As stated previously, this school had a high-performance culture that could motivate students and teachers to succeed all school programs. Nine unwritten school systems were the example of how they could influence the belief, perception, and attitude of the students to be active in 2 of 32 extracurricular lessons. It was in line with Jones and Blake (2017) who stated that some aspects of school culture like beliefs, values, perceptions, relationships, attitudes, and written and unwritten rules could shape and influence every aspect of how a school functioned.

The result of the study showed that the description of the students' motivation as one of the main factors that contributed to the successful students in learning English through e-learning was in line with the following literature. Jacobson (2009) found that motivation was one of the most powerful elements for achievement outcomes in school systems. In fact, the motivation influenced the students to get many achievements. Meanwhile, Macneil, Prater, and Busch (2009) found that the school culture and school climate of feeling comfortable to study could influence the student's motivation to study. Simply, the high academic performance of SMP TGP gave an indirect contribution to the learner success in e-learning through the improvement of the students' motivation and students' e-learning self-efficacy. Besides, the students' prior knowledge in the computer and internet literacy also improved the students' self-efficacy in elearning.

In this ethnographic case study, school culture was an important factor to explore what existed behind the learner factors and institutional factors. This school had a long history to be called as "Sekolah TGP". This school was 
established in 1979 and up to now all stakeholders (principal, teachers, students, alumni and parents) of this school still believed that TGP (Tentara Genie Pelajar) gave a contribution to create the values and beliefs of the school to be a high-performance or high achievement culture school. The beliefs and values held by the students and teachers directed this school to be an excellent school that had many achievements in the regency, province, and national level. Nor and Roslan (2009) suggested all stakeholders, especially the school principal, to care a school culture because "a caring school culture helps build positive relationships, a sense of belonging, and positive self-concept amongst members of the school". Spicer (2016) said that "school culture" is more focused on implementing the beliefs and values that reflect or represent the common behaviors that characterize the school. School culture is created from a long process and period and it is not easily changed. School culture here was all the interactions, practices, expected behaviors and values that impacted how this school operated. As a part of socio-constructivism, school culture in SMP TGP was developed in coordination and interaction with individuals in and out of this school. The influence of the Tentara Genie Pelajar alumni to build a nationalism and discipline value created good characters, interactions, written and unwritten rules or strategies which were practiced very well by the students, staffs, teachers, and leaders of this school in the daily school life.

\section{CONCLUSION}

SMP TGP was established in 1979 and all stakeholders (principal, teachers, students, alumni and parents) of this school still believed that the culture of TGP (Tentara Genie Pelajar) gave a contribution to creating the habits, values and beliefs of the school. The beliefs and values held by the students and teachers pushed this school to be an excellent school which successfully got many achievements in the regency, province, and national level. These achievements created this school to be a high-academic performance school culture. The fundamental finding of the study showed that the high-academic performance culture of this school gave an indirect contribution to the learners' e-learning success factors. The school culture indirectly motivated the students to accomplish the e-learning tasks and to win the e-learning competition. The students' prior knowledge on the computer and internet literacy that the students had learned at school, especially in the Bilingual Class, also indirectly gave a contribution to improving the students' elearning self-efficacy. Besides, the good relationship between the instructor and the students also created the student-instructor interactions and the studentcontent interaction could run well.

Journal on English as a Foreign Language, 8(2), 149-169

Copyright (C) 2018 by JEFL, p-ISSN 2088-1657; e-ISSN 2502-6615 
The future work should explore the critical success factors from the institutional factors or the outcome factors that influence the success of the students in e-learning. The big implication of the study is able to change the mindset of the Indonesian researchers to explore more the school culture by using an ethnographic approach at school. Moreover, the finding also has a practical implication to Indonesian schools and universities to learn how to succeed their e-learning programs.

\section{REFERENCES}

Ali, M. (2005). E-learning in the Indonesian education system. Asia-Pacific Cybereducation Journal, 1(2), 15-24. Retrieved from http://db.koreascholar.com/article?code=244040.

Ali, N., Sharma, S., \& Zaman, A. (2016). School culture and school effectiveness: Secondary schools in Pakistan. MOJEM: Malaysian Online Journal of Educational Management, 4(4), 50-65. Abstract. doi: https://doi.org/10.22452/mojem.vol4no4.4. Retrieved from http://mojem.um.edu.my/index.php/MOJEM/article/view/6059

Anderson-Levit, K. M. (2006). Ethnography. In J.L Green, G. Camili, \& P.B. Elmore (eds), Handbook of Complementary Methods in Education Research (pp. 279-295). Washington, D.C: American Educational Research Association.

Aparicio, M., Bação, F., \& Oliveira, T. (2016). Cultural impacts on e-learning systems' success. The Internet and Higher Education, 31, 58-70. 10.1016/.iheduc.2016.06.003.

Basit, T. N. (2003). Manual or electronic? The role of coding in qualitative data. Analysis Institute of Education Manchester Metropolitan University. Educational Research, 45(2), 143-154. DOI 10.1080/0013188032000133548.

Boeije, H. R. (2010). Analysis in qualitative Research. University of Utrecht: Sage Publication, Inc.

Brooks-Young, S. (2007). The digital age literacy for teachers: Applying technology Standards for Everyday Practice. Oregon: International Society for Technology in Education (ISTE) Publications.

Brown, J. S. (2002). Learning in the digital age. The Internet $\mathcal{E}$ the university: forum 2001 edited by Maureen Devlin, Richard Larson and Joel Meyerson. Published as a joint project of the Forum for the Future of Higher Education and EDUCAUSE. Retrieved from http://www.johnseelybrown.com/learning_in_digital_age-aspen.pdf.

Creswell, J. W. (2007). Qualitative inquiry and research design: Choosing among five traditions (2nd Ed.). Thousand Oaks, CA: Sage Publications. 
Creswell, J. W. (2008). Educational research: Planning, conducting, and evaluating quantitative and qualitative research. New Jersey: Pearson Education, Inc.

De Sousa, J. M. E. (2011). Definition and analysis of critical success factors for ERP implementation project. (Doctoral Dissertation). Universitat Politècnica de Catalunya, Barcelona. Retrieved from http://jesteves.com/Tesis_phd_jesteves.pdf.

Dudeney, G., \& Hockly, N. (2007). How to teach English with technology. Edinburgh Gate Harlow Essex: Pearson Education Limited

Eagleton, M., \& Dobler, E. (2007). Reading the web: Strategies for internet inquiry. New York: The Guilford Press.

Fraenkel, J. R., Wallen, N. E., \& Hyun, H. H. (2012). How to design and evaluate research in education ( $8^{\text {th }}$ Ed.). New York: McGraw-Hill Companies, Inc.

Howell, M. T. (2010). Critical success factors simplified: Implementing the powerful drivers of dramatic business improvement. New York: Taylor and Francis Group.

Klenke, K. (2008). Qualitative research in the study of leadership. Bingley: Emerald Group Publishing.

Kusumo, N. S. A. A., Kurniawan, F. B., \& Putri, I. N. (2012). ELearning obstacle faced by Indonesian students. Special Issue of International Journal of the Computer, the Internet and Management. 19(SP2). Retrieved from http://www.ijcim.th.org/SpecialEditions/v20nSP1/v20nSP1.htm.

Macneil, A. J., Prater, D. L., \& Busch, S. (2009). The effects of school culture and climate on student achievement. International Journal. Leadership in Education, 12(1), 73-84. Retrieved from http://donnieholland.wiki.westga.edu/file/view/school+culture+ climate+\%26+achievement.pdf

Mason, R., \& Rennie, F. (2006). E-learning the key concept. New York: Roudlege.

Musa, M. A., \& Othman, M. S. (2012). Critical success factors in E-learning: An examination of technology and student factors. International Journal of Advances in Engineering \& Technology, 3(2), 140-148. Retrieved from http://citeseerx.ist.psu.edu/viewdoc/download?doi=10.1.1.667.1861\&rep= rep1\&type $=$ pdf.

Nor, S., \& Roslan, S. (2009). Turning around at-risk schools: What effective principals do. International Journal on School Disaffection, 6(2), 21. Retrieved from http:/files.eric.ed.gov/fulltext/EJ853212.pdf

Noytim, U. (2006). The Impact of the internet on English language teaching: A case study at a Thai Rajabhat University. (Doctoral Dissertation). Retrieved from https: //opus.lib.uts.edu.au/research/bitstream/handle/2100/384 02whole.pdf? sequence $=2$. 
Ordóñez, A. C. (2014). Predicting international critical success factors in e-learning: A comparison of four universities from China, Mexico, Spain and USA. (Doctoral Dissertation). Universitat Oberta de Catalunya. Retrieved from https://www.tesisenred.net/bitstream/handle/10803

276198/Thesis\%20Armando\%20Cortes_24_Jul_2014_ok.pdf?sequence=1 \&isAllowed $=\mathrm{y}$

Ordóñez, A. C., \& Barbera, E. (2013). Cultural differences in students' perceptions Towards online learning success factors. Proceedings of $12^{\text {th }}$ European Conference on e-Learning, 12, 555. Retrieved from https://issuu.com/acpil/docs/ecel2013-proceedings-vol2.

Selim, H. M. (2007). Critical success factors for E-learning acceptance: confirmatory factor models. Science Direct: Computers E Education, 49, PP. 396-413. doi: 10.101016/.compedu.2005.09.004

Son, J. B, Robb, T., \& Charismiadji, I. (2011). Computer literacy and competency: A survey of Indonesian teachers of English as a foreign language. Computer Assisted Language Learning Electronic Journal, 12(1), 26-42 Retrieved from http://callej.org/journal/12-1/Son_2011.pdf.

Spicer, F. V. (2016). School culture, school climate, and the role of the principal. (Doctoral Dissertation). Georgia State University. Retrieved from http://scholarworks.gsu.edu/cgi/viewcontent.cgi?article=1174 \&context=eps_diss .

Sridharan, B. (2011). Evaluating the critical success factors for sustainable e-learning ecosystems in tertiary education. (Doctoral Dissertation). School of Business IT and Logistics College of Business RMIT University. Melbourne. Retrieved from http://citeseerx.ist.psu.edu/viewdoc/ download?doi=10.1.1.660.8018\&rep=rep1\&type=pdf.

Sulistyo-Basuki, L. (2007). IT and education, the case study of e-learning in Indonesia. Paper presented in Korea-ASEAN Academic Conference on Information Revolution and Cultural Integration in East Asia, Ho Chi Minh city, Vietnam, January 25-26. Retrieved from http://eprints.rclis.org $9048 /$.

Sun, P. C., Tsai, R. J., Finger, G., Chen, Y. Y.,\& Yeh, D. (2008). What drives a successful e-learning? An empirical investigation of the critical factors influencing learner satisfaction. Computers $\mathcal{E}$ Education, 50(4), 1198311202. DOI: 10.1016/.compedu.2006.11.007

World Economic Forum. (2016). Global information technology report: Network readiness index. Retrieved from http://reports.weforum.org/globalinformation-technology-report-2016/networked-readiness-index/.

Yin, R. K. (2011). Qualitative research from start to finish. New York: The Guilford Press. 
Zainon, O., Masrom, M., \& Rahiman, R. (2008). E-learning critical success factors: The student's perspective in Mohd Fuad Mohd Salleh (ed). Elearning issues in Malaysian higher education. Kuala Lumpur: UTM Press.

\section{Authors' Brief CV}

R. Chusnu Yuli Setyo is a researcher at the Islamic University of Lamongan (Unisla). His primary area of expertise is teaching English as a foreign language. He currently works to develop a program of leadership and partnership for youths with East West Center (Hawaii, USA) and Hiroshima Prefectural Board of Education (Japan). He almost accomplishes his study in a doctoral program of The State University of Surabaya (Unesa).

Suharsono Suharsono is the senior lecturer at the State University of Surabaya (Unesa). He attained his Master's in Sociolinguistics from Murdoch University and his $\mathrm{PhD}$ in Anthropological Linguistics from University of Western Australia.

Oikurema Purwati is the senior lecturer at the State University of Surabaya (Unesa). She earned her Master in Applied Linguistics (Linguistics, TEFL, Language Assessment and Testing, and Language Research) and Graduate Diploma in English Literature from Monash University. Her Doctor was pursued from State University of Malang majoring English Language Teaching (ELT). 